\title{
Let's Hash Out the Issues in Auditing Recreational Marijuana Businesses Before the Opportunities Go Up in Smoke
}

\author{
Daphne Rixon \\ Saint Mary's University \\ Pauline Downer \\ Memorial University of Newfoundland \\ Alex Faseruk
Memorial University of Newfoundland
}

Within North America, there is a plethora of regulations regarding the accounting, taxation, and auditing of medical and/or recreational marijuana given conflicting treatment within various jurisdictions in either Canada or the United States. This study focuses on examining the auditing issues firstly in the United States where recreational cannabis is allowed in nine jurisdictions with 29 allowing medical usage. Canada is then considered wherein medical marijuana is allowed nationwide with recreational marijuana becoming legal on October 17, 2018. The study identifies the lack of meaningful auditing standards and comments where additional pronouncements are required to enhance transparency and heighten investor confidence.

\section{INTRODUCTION}

This paper identifies the key challenges that auditors in Canada will encounter as a result of the legalization of recreational marijuana scheduled for July 1, 2018 but postponed until October 17, 2018. It examines the potential impact on attest and compliance auditing. At present there is a conundrum in the treatment of both medical and recreational marijuana in North America. Commercial cultivation and production of industrial hemp was legalized in Canada in 1998. The usage of medical marijuana has been permitted since 2001, largely through court cases which have upheld its usage, albeit confined to situations as specified by Health Canada. However, recreational marijuana is still illegal in Canada with failed bills in Parliament to decriminalize in 2003 and 2004.

In the United States, the usage of medical marijuana is not as widely recognized as it is in Canada. Only 29 states allow its usage. However, eight states (Alaska, California, Colorado, Maine, Massachusetts, Nevada, Oregon, and Washington) and the District of Columbia have legalized recreational marijuana (Lu-Andrews \& Wang, 2017). Notwithstanding, the legalization of recreational marijuana by these nine jurisdictions, recreational marijuana is still a federal offense. The American President has directed the Attorney General to enforce the various laws restricting marijuana. At present, 
there are several different and conflicting laws and, therefore, differing business models at play within the various market segments of what may constitute the marijuana industry. In turn, there are different accounting procedures that are being employed across jurisdictions, which exacerbates how audits would be conducted in these businesses. Moreover, there are several medical marijuana-based companies that trade on exchanges. While these companies are subject to public audits, the question quickly arises whether the auditing standards that are applied to medical marijuana will still be applicable to recreational marijuana or whether adjustments would need to be made. Accordingly, it is important to postulate on the impact of legalization of marijuana in Canada as it may well require new skills to be developed in order to correctly complete attest and compliance audits. This study is undertaken using the American experience as a backdrop.

The importance for correct audit procedures for companies involved in the marijuana sector cannot be understated as new public companies are incorporated, raise capital in public listings, need due diligence to be performed for mergers and acquisitions, engage in joint ventures (no pun intended), form innovative industrial properties (IIPR) as a real estate investment trust (REIT) and are included in exchange traded funds (ETF) listed on stock exchanges.

The first section has provided a summary of the salient issues in general terms related to the business models, while introducing the need for enhanced accounting and auditing procedures. The second section examines the American accounting and auditing experience against the experience of auditing medical marijuana in Canada to provide the necessary caveats for Canadian companies as they move toward recreational marijuana in their product mix. The third section provides specific areas for auditors to be concerned. The fourth section concludes the paper.

\section{THE AMERICAN AUDITING EXPERIENCE PRIOR TO CANADA'S LEGALIZATION}

With the proposed legalization of recreational marijuana in Canada, there are significant accounting issues that must be addressed, as they would in any other business. These accounting procedures reflect not only the nature of the business or industry, but also need to be used for correct taxation and auditing for both assurance and compliance functions.

In the United States, many CPA firms in the states where recreational cannabis is permitted have begun to advertise cannabis accounting services. In so doing they are portraying themselves as qualified accountants with experience in the cannabis industry. Cornelius CPAs promotes themselves as one of the first public accounting firms to offer accounting services to the cannabis industry in Colorado, saying that they work with licensed medical and recreational marijuana dispensaries, cultivation facilities, infused production facilities and quality control testing labs, as various components in the value chain. They further claim that they have pioneered an accounting model recommended for their clients and that they,"... also perform [sic] the following services for our cannabis clients":

http://corneliuscpas.com/cannabis_accounting.php.

1. Maintain accounting records

2. Prepare weekly and monthly payroll

3. Prepare federal and state income tax filings

4. Prepare sales and excise tax filings

5. Recommend and assist in implementing legal business structure and formation

6. Conduct financial statement audits, reviews and compilation for owners, investors and Banks

7. Perform forensic accounting examinations when fraud or theft is discovered

8. Prepare financial and accounting policy and procedures

9. Prepare internal control evaluations for existing businesses to discover weaknesses

10. Provide financial consulting services for business owners for a variety of financial areas

Camico (n.d.) in its cautionary note, "Marijuana Business Clients: 'Smokin' Hot' Issues for CPAs" identified and outlined several issues that are to be addressed to CPAs who may become involved in this emerging and potentially risky future area of business, which were: Banking Problems; Policy Issues; Risk Management Considerations; Is This a Client the Firm Would Like to Have?; Accountant-Client 
Privilege; Client Screening; Federal Income Tax Treatment for Marijuana Business Clients; and Accounting Treatment for Marijuana Businesses Clients.

Conversely, Canna Recruiter (n.d.) in its advertisement outlined several opportunities for employment in the cannabis industry, "Marijuana Accounting Jobs: The Devil is in the Details," which dealt with such opportunities as: Cannabis and the Big Banks; Marijuana Accounting Jobs Today; Legal Risks; What are Marijuana Accounting Jobs?; Job Qualifications \& Prerequisites; Dispensary Manager; Best Cities for Marijuana Accounting Jobs (Denver, Colorado, Sacramento, California, Portland, Oregon); and, The Future of Marijuana Accounting Jobs.

Finkbenbinder (2016) in "Cannafinance Accounting: The Necessary Evil for a Successful Cannabis Business," outlined what she considered to be the requisite conditions for successfully accounting in the marijuana business to be compliant with various laws and conventions by examining such topics as: How is Accounting for a Cannabis Business Any Different; Section 208E Compliance; Set up the Books for Cost Accounting; What Expenses Can Be Included as Direct Costs; and Consistency is the Key.

AICPA, the Colorado Society of Certified Public Accountants (COCPA) and the Washington Society of Certified Public Accountants (WSCPA) jointly issued a brief on July 24, 2015 and issued a revised brief on January 8, 2016, "An Issue Brief on State Marijuana Laws and the CPA Profession" in order to prepare CPAs to provide accounting services to marijuana firms.

While offering accounting services other entities such as The Henry Levy Group in its industry brief 8 Common Accounting Problems Cannabis Businesses Face (December 31, 2014) outlined these potentially extensive problems:

Problem \#1: Not Knowing About the Cannabis Industry, State Laws, and Tax Law

Problem \#2: The (Near) Impossibility of Getting a Bank Account

Problem \#3: Not Keeping Track of Your Accounts

Problem \#4: The Living Nightmare Also Known as Being Audited

Problem \#5: Not Understanding Crucial Business Software

Problem \#6: Not Being Familiar with Cannabis-Friendly Business Merchants

Problem \#7: Needing to Safeguard Your Inventory Assets

Problem \#8: Not Knowing Any Relevant Business Consultants

One of the most pressing issues in the United States is adherence to IRS Section 208E of the tax code which prohibits deduction of expenses in a marijuana business unless they relate to the cost of goods sold (Schroyer 2017). In this article entitled "Industry snapshot: Accounting Services for Marijuana Businesses-Data, trends and challenges" from Marijuana Business Magazine, Schroyer portrayed five warning signs (in the shape of traffic signs, such as a stop sign) on the front page of the article and discussed tax in some form on each subsequent page of the article.

Coren (2016) contends "The pot industry is desperate for good accounting software" wherein he reports that there were 727 companies dealing in cannabis with the investment totaling $\$ 1.2$ billion. An additional \$20 million investment is made each quarter. Legal sales of marijuana topped $\$ 4$ billion in 2016. The top five segments of the 17 reported in the market attracting these investments are:

1. business software;

2. media outlets and social networks;

3. dispensaries and retailers;

4. edible products; and

5. oil-based products.

The bottom five issues (13 through 17) are:

13. drug testing services;

14. IP-holding groups;

15. general medical marijuana;

16. lab testing; and

17. rehabilitation programs. 
Similarly, Tax Audit Pros as Certified Public Accountants (CPAs) in an online brief outlined similar issues on how to function effectively as marijuana accountants and touched on most of the same issues (Tax Audit Pros-Certified Public Accountants (CPAs), 2017).

Cannacomply (2017) outlined the issues necessary to set up an accounting system for the cannabis industry. They are marketing accounting software to demonstrate how to be compliant with various conventions that would aise in an audit situation. They contend it is not a matter if being audited, but when.

Notwithstanding that there are various concerns about the accounting issues surrounding marijuana, Stevens (2015) in "A Cannabis Niche for Accountants? Working with Businesses that Grow and Sell Marijuana" points out that cannabis is a booming business ripe with opportunities for an accounting practice to work and consult with businesses in the marketplace on a full range of tax, sales tax, accounting, audit and workflow issues. At the time of the article in 2015, he pointed out that 23 states and the District of Columbia allowed marijuana for medical use and that four states at the time had allowed it recreationally (Alaska, Colorado, Oregon and Washington), but that seemed only to be the beginning and that marijuana sales by 2019 could reach $\$ 10.8$ billion (Stevens, 2015). Consider that at the time of the General Election on November 8, 2016, Arizona, California, Maine, Massachusetts, and Nevada all voted to legalize recreational marijuana for adults older than 21, while four more states Arkansas, Florida, Montana and North Dakota voted to ease access to medical marijuana (Coren 2016). There, however, still exists one major risk for marijuana businesses as the Drug Enforcement Agency still classifies marijuana as a Schedule 1 (1970) drug with, "no currently accepted medical use and a high potential for abuse" (Coren 2016).

In order for marijuana to become a fully legal commodity, very specific accounting rules need to be followed, which would, in turn, would present numerous auditing implications. Without the aid of direct pronouncements on the subject for recreational marijuana, many accounting firms would currently be in uncharted territory, especially in Canada, given the nationwide reach of the legislation.

Consider the article by Freeman (2017) in the Financial Post, the leading daily business newspaper, carrying the title, " 'Biological assets': accounting rules are adding haze to marijuana company financials." She points out that there is the potential for confusion, especially for the retail investor, which has resulted in calling on marijuana companies themselves to be more transparent. She further contends that publicly-traded cannabis companies are not exactly sure what to make of it either. She demonstrates that the current accounting procedures for the 'biological asset' rule may lead to misstatement of income as it pre-books income for crops as they are growing. International Accounting Standard 41 sets out accounting for agricultural activity to measure the transformation of biological assets (living plants and animals) into agricultural produce (harvested product of the entity's biological assets). The standard generally requires biological assets to be measured at fair value less costs to sell. Specifically, the biological asset rule credits the value of product that is growing at fair value minus selling costs and reports that figure on the income statement. Therefore, a company can report net income in a quarter during which they grew or harvested marijuana, but did not have any actual sales. The sales can be under or over stated based on fluctuations in price, which would lead to volatility in net income.

Freeman (2017) contends that these rules are actually creating an accounting burden on these companies as they have to spend time to value the crops and/or hire experts to undertake this role. The potential for confusion, especially to the retail investor, is that booked income may not materialize which would result in a future loss. Accrual accounting in this instance may make more sense, unlike in many states where marijuana sales are on a cash only or mostly cash business.

Freeman (2017) cites three of the largest medical marijuana companies in Canada, Canopy Growth Corp., Aphria Inc, and Aurora Cannabis Inc., neglected to disclose the impact of biological assets in their press releases for their most recent quarters, although they elaborated on these impacts in their management discussion and analysis document, but still have large effects. In Canopy's most recent quarter, the unrealized gain on the changes in the fair value of the company's biological assets amounted to $\$ 18.2$ million, double its actual revenue of $\$ 9.8$ million, thereby overstating the value of their 
biological assets. By being too liberal with assumptions could lead to future periods with non-matching inventory. Neither auditors nor investors take kindly to these types of misstatements.

McCullough (2018) in an article published in CPA Canada Pivot Magazine demonstrates the concern that requires publicly-listed cannabis companies to comply with the IFRS requirement to record unsold inventory at fair value. At the time of the writing of this article, which is prior to the legislation coming into force, the legal market for these products had not yet been established. Consequently, the demand is unknown and price cannot be confirmed. As was already argued previously in this article, the market for cannabis is not a single homogeneous product. There are actually several products, which could exhibit differing degrees of turnover, which would result in different ordering and carrying costs per product. McCullough against his backdrop and these insights argues very cogently that such an arbitrary inventory valuation approach is speculative and could result in confusion on behalf of investors.

Descoteaux (2018) in another CPA Canada Pivot Magazine article outlined the challenges associated with accurately predicting the size of the Canadian market. He explained that the success that Colorado witnessed might not be replicated in Canada. As Colorado had a significant market created from surrounding states that had not yet legalized marijuana. In addition the two largest provinces in Canada in terms of population, plan to sell the product through their government-owned liquor stores, which may result in potentially lower sales as customers may be reluctant to transition from the black market to a government-owned entity. Moreover, Descoteaux also notes that profit margins might not be as high as forecast due to various taxes at both the federal and provincial levels which would erode profitability.

According to McCullough, Deloitte advised Canopy Growth to adhere to IFRS rules for agricultural companies. This process means booking the unsold plants at fair market value which subsequently results in a profit. This valuation process for agricultural enterprises was designed for long-lived assets, such as live animals or trees, in order to enable them to illustrate the value created in the long lead time before the products were harvested and sold. In comparison, marijuana has a short lead time in the range of 6-20 weeks. McCullough further notes that some companies are taking it upon themselves to create greater transparency by including non-IFRS metrics along with their financial statements. For example, MedReleaf, Aphria Inc., and Canopy Growth have all adopted a reporting approach whereby a gross profit line that does not reflect fair value is inserted above IFRS-defined gross profit.

At this point, those agencies that set accounting standards largely appear to be taking a 'wait and see' approach. McCullough (2018) reports that Linda Mezon, chair of the Accounting Standards Board (AcSB) plans to wait until "...the fuss over legalization and volatility in the market settles down, the question over whether the standard is appropriate will be clearer." Mezon further states that they will, "...work with the industry to identify things that need to be done." Cleary, the agencies setting the standards need to work with the industry to provide standards that address the needs of the cannabis industry. The current lack of standards will undoubtedly result in challenges for auditors.

In returning to the question of biological assets that introduced this section, it is demonstrated that this situation was exacerbated by the lack of standards and the current wait and see attitude. This wait and see attitude represents a reactive posturing for the cannabis industry, whereas a proactive stance is what the industry needs to provide transparency for investors and quality information management for decision-making. Consider the recent experience of Aphria and Aurora in recording biological assets.

Aphria highlighted in its most recent MD\&A that biological assets were worth $\$ 533,402$, while the net effect of unrealized changes in the fair value of those assets amounted to $\$ 74,268$ in the quarter ended November 30, 2016. It explained that in order to determine the fair value of those assets requires management to make a number of estimates including the expected cost necessary to cultivate marijuana to the point of harvest, harvesting and selling costs, anticipated sales price, and expected yield for crop. Given the requirement of conservatism, it is better to understate rather than overstate (Freeman, 2017). However, systematic understating is frowned upon by the markets as well.

Aurora touched on the impact of biological assets in its discussion of gross margin through explaining that in the previous year's period that the company did not generate any revenue from sales owing to the fact that they had not started the distribution part of their business, but recorded changes on the fair market value of biological assets of $\$ 2.2$ million on the inventory that it had amassed. For this reason, the 
company recorded a net loss of $\$ 2.7$ million in the second quarter of 2017 , when it was selling product, but a $\$ 600,000$ gain in the previous year for the same quarter. This anomaly was addressed in the company's management discussion.

Needless to say, there are significant accounting issues that are endemic to the cannabis industry, which has potential to become exacerbated as more firms enter the industry or as existing firms expand to service the increased demand when recreational marijuana is legalized. The current accounting practices carry the risk of write-downs of inventory, if the price per gram were to fall or if the inventory remains unsold for a significant time, which may detract investors from entering the market (Freeman 2017). Accordingly, the market may not have the liquidity that it should have with the results that mergers might take place. Mergers would restrict competition, the illegal market in marijuana would continue, and these legitimate companies may become the target of money laundering. What is needed is an enhanced industry-wide metric (possibly non-IFRS as they are also silent on the subject) that would better account for cultivation, processing, and distribution that would not front-load income. There is also the potential for shrinkage, which can be legitimate, such as loss of moisture (although taxes are assessed on dry weight), which is experienced in many other agricultural commodities as recognized on future exchanges, or illegal, such as various pilferage activities. Lastly, the emphasis in this industry has centered on the active chemical ingredients within cannabis, namely THC and CBD, but there is also the potential for other products that can be produced from the marijuana plant, such as hemp rope, paper, jewelry, fashioned into various other products like baskets, or made into plastics.

For publicly traded firms, providing assurance to investors is of paramount concern. Auditing for the purpose of becoming a fully reporting public company will become an important issue as more companies approach the capital markets as public firms to raise capital and trade on stock exchanges, as was outlined by Market Wired in its article of December 27, 2016 (Market Wired, 2016) entitled, "Marijuana Company of America has Engaged Auditing Firm to Prepare for Move to Fully Reporting Public Company."

The Marijuana Company of America (MOCA) Inc. (OTC PINK: MOCA), an innovative cannabis and hemp marketing company, engaged L\&L CPAs PA as its independent audit firm to complete a two-year audit as part of the process to become a fully reporting public company with the intent of moving from the over the counter (OTC) market to a listed exchange. In so doing, the engaged auditors are working with MOCA's legal counsel to complete the necessary procedures to file a registration statement with the Security and Exchange Commission (SEC) in order to enhance its long-term shareholder value, while attracting a broader and more diverse shareholder base. All these reasons cited by the company are no different than any other firm that wants to raise capital and trade on a listed exchange, but it is the nature of the product and the climate of the market that will dictate enhanced scrutiny on firms engaged in the marijuana business. The question remains whether or not the current state of auditing procedures can fully meet the requirements of investors and the various regulating authorities.

In the words of MOCA's CEO, Donald Steinberg, "Our goal is to be a fully transparent reporting company. As we grow and take these major steps, we want our shareholders to be well-informed about our plans and our progress. By becoming a fully-reporting, transparent public company, we may be better positioned to enhance stock liquidity and attract institutional investors, which will fundamentally enhance the value of our Company." Nothing in this CEO's statement would be considered out of line with any other public company trading in the OTC market that wanted to subsequently trade on a listed exchange. Interfacing with the auditors and the legal teams is a normal business practice for publicly traded companies. However, given the newness of this movement in the cannabis industry, it was very noteworthy that the CEO would make such an up-front announcement.

Steinberg (in Market Wired, 2016) said, "Our goal is to be fully reporting on the most reputable exchange we qualify for, so our shareholders have all the information they need to follow our progress in detail." L\&L CPAs, PA is registered with the PCAOB and is experienced in conducting audits of public companies in the cannabis industry. Completing this audit will help to ensure the accuracy and completeness of MCOA's financial information, as well as to identify and perhaps strengthen its internal controls over financial reporting. 
In estimating revenues from marijuana sales Phillips (2015) outlined several factors that could negatively impact marijuana revenue as: federal intervention (most likely in the form of federal prosecutions against a controlled substance); legalization's effect on marijuana prices; tax evasion (the specter of Al Capone could still haunt this market); treatment of homegrown marijuana (i.e., the ability of individuals to grow their own marijuana on a small scale as Alaska, Colorado and the District of Columbia each allow individuals to grow up to six plants per person for non-medical purposes: Oregon permits four plants to be cultivated, while personal cultivation is not allowed in Washington); and the substitution of marijuana for alcohol.

The question of whether marijuana is a complementary good or a substitute good would need to be ascertained for revenue to be estimated. As a complementary good, it would be in the situation when one smokes marijuana and uses a beer as chaser. In this case, the complementary good would suggest that both goods would increase. This approach may suggest that a utility maximizing individual would not have a restrictive budget line or would increase both goods in predetermined proportions.

As a substitute, one would forego consumption of beer in favor of marijuana or vice versa. The economic laws of cross elasticity of substitution would apply in the latter case. The existence of complementary and substitutes are important in forecasting revenues as part of the auditing process.

A third alternative which may become relevant is whether or not hemp-based beers become popular. In this case an endogenous demand becomes relevant, that is to say the proportion of the grow-up's crop that would be devoted to beer production. If the marijuana producer does not want to invest in beer brewing production facilities, it may choose to outsource to an existing brewer, which produces other auditing issues, such as the yield that would be expected in producing beer. Shrinkage and quality control issues become highly relevant in the brewing process, particularly when brewing is done off site.

Philips (2015) also outlined factors that could positively impact marijuana revenue as: legalization's effect on marijuana consumption (which is expected to increase); marijuana tourism; and legalization's impact on income tax revenues. One area that he did not consider was the potential for sales of marijuana seeds for personal consumption or even the cultivation facilities which may improve the strains of marijuana or broaden the market through different types. Of course, distribution could be a problem as marijuana would not be allowed to be shipped by mail and across various borders, for example.

How does one treat and measure ancillary products, such as rope and baskets or refined into plastics that can be produced from parts of the plants which do not have active ingredients? Further products which have active ingredients, such as marijuana edibles, chewing gum, marijuana butter, or various in tinctures can also be produced. Under the current legislation marijuana edibles are not allowed. A standardized auditing plan with attest functions based on formula yields is undoubtedly very far from being developed.

While there are many auditing issues for publicly traded marijuana firms, in many ways this is just the tip of the iceberg as compliance auditing for state (provincial) regulators and the IRS (Canada Revenue Agency) will become widespread as additional businesses enter this potentially lucrative market. Consider Schiller (2017) of the Cannabis Business Times in her article "New Compliance Tool Designed to Simplify Auditing" with the sub-title "Simplifya's CTO shares how cultivators can use the software to increase compliance through self-audits and better prepare for state inspections."

Similarly, Cannabis Compliance Audits were shown to have benefits by the Denver Consulting Group (n.d.) (self-proclaimed as Colorado's Cannabis Experts) to provide assurance to banks and bankers, investors, landlords, realtors, government officials and bodies, licensees, insurance companies in providing various types of cannabis compliance audits (Retail Marijuana Center (recreational store), Medical Marijuana Center (medical store), Retail Marijuana Cultivation Facility (recreational grow), Optional Premises Cultivation (medical grow), Retail Marijuana Product Manufacturing Facility (recreational kitchen/concentrate processor) and Marijuana Infused Product Manufacturer (medical kitchen/concentrate processor) with the benefits from a compliance audit of providing (Objective $3^{\text {rd }}$ Party Assessment of Compliance; Thorough, Quantitative, and Applicable Reports; Create a Culture of Compliance; Proof of Due Diligence; Establish a History of Compliance; Peace of Mind). There advertisement ends with the advice, "Schedule your cannabis compliance audit today." 
Notwithstanding the desire by auditing firms to provide auditing services to be compliant with accounting rules and regulations, there is still the stigma which goes with the cannabis business. For example, the Internet carries such articles as, Migoya (2017) "DOJ is secretly using IRS to investigate Colorado pot shops in guise of audits, lawsuit says" but it also carries the denial from the IRS as it says, "IRS says it just wants to determine what shop owes in taxes." Daniels (2016) in "IRS said to be auditing Colorado marijuana businesses" and Yakowicz (2016) in "Why the IRS Is "Aggressively' Auditing a Bunch of Colorado Cannabis Companies" had already made similar points regarding the then anticipated audits. Oregon may well be next; Alice of "I Love Growing Marijuana" (2017) writes "Attorney General and Cannabis Auditing is Coming to Oregon."

Paying taxes in cash and auditing a cash-only business may be a problem as outlined by Dollow (2017), "Paying taxes in cash, marijuana companies have a lot to hash out with IRS" and Arrowsmith (2017) "IRS goes green: Hashing out payments from the marijuana industry." Wells (2014) had written that at that time the IRS would be concerned more with the collection of taxes than with prosecution in her article, "Accountants exhale after IRS takes stand on pot." However, what is disconcerting is that the attitude and rules change and evolve over time.

The California Cannabis CPA (n.d.) in the article "Lowering the Risk of an IRS Audit for your Marijuana Business" provides the rather cogent observation that every cannabis company has a substantially higher risk of being audited with the best practices to reduce the chance of being audited with three rules: 1. Maintain Careful Records and Copies; 2. Make Sure to File on Time; and 3. Comply with All State Laws. Throughout the discussion there is the implicit assumption that the business is using the services of a CPA.

According to the AICPA, 12 state boards have issued official guidance for auditors offering services to the marijuana industry https://www.aicpa.org/advocacy/state/pages/marijuana.aspx. However, it appears that there is no national guidance due to the American federal legislation regarding marijuana. The AICPA provides links to resources such as the various state regulations and has issued the following summary guidelines drawn from the state regulations:

- Providing accounting services to marijuana businesses operating within the boundaries of state law is, in itself, not an act discreditable, nor does such service constitute a lack of good moral character;

- The state board of accountancy will not pursue independent disciplinary action against licensees who are providing services to business in the marijuana industry that are operating within the boundaries of state law where services are being provided, notwithstanding a successful prosecution of a criminal act;

- The state board of accountancy will not speculate on state or federal drug policy enforcement nor seek to interpret any state's marijuana laws that are not directly related to the practice of public accountancy;

- While the state board will not sanction licensees solely for providing services to state-legal businesses in the marijuana industry, the board's position does not negate the possibility that disciplinary action may be taken by the board should a licensee be found guilty of a criminal act. The board will treat any successful prosecution related to federal or state marijuana laws just as it would the prosecution of any other criminal act;

- The state board strongly recommends that CPAs or CPA firms interested in providing services to businesses in the marijuana industry seek legal counsel to discuss potential risks, including but not limited to the continued uncertainty surrounding enforcement of applicable federal or state drug laws, anti-money laundering laws and related provisions of the Internal Revenue Code.

Clearly, the AICPA has provided very cautionary advice on legal matters to its members, but has neither provided guidelines nor directives on the provision of accounting services or the conduct of audits. 


\section{ISSUES INVOLVING THE AUDITING OF LEGALIZED CANNABIS IN CANADA}

Although an examination was made in the preceding section concerning the initial state of auditing in the United States for recreational marijuana and in Canada for medical marijuana leading to recreational marijuana, there still exists several issues concerning the auditing for recreational marijuana in Canada, which may mean the development of national auditing standards in Canada to fully give transparency and accountability in this burgeoning industry.

The first issue deals with whether auditors will have the knowledge and expertise to conduct an audit of compliance to federal and provincial government regulations with respect to the cannabis business, which, of course, reflects the 150-year concern of whether laws and sundry regulations are federal or provincial concerns. For example, under the Canadian constitution, criminal law is the exclusive domain of the federal government whereas taxation can be both a federal and provincial concern. The proposed legislation which would come into force on October 17, 2018 not only decriminalizes marijuana, but specifically allows recreational marijuana, albeit as a controlled substance, not unlike alcohol and tobacco. Other controlled substances are subject to taxation, such as excise duties and sales taxes. The federal government has superior taxation powers that is to say by any means, whereas provincial governments are restricted to direct taxation. So, it was not surprising when the Prime Minister first announced that there would be a $10 \%$ tax on marijuana and that the proceeds from taxation would be equally split. This announcement generated almost immediate controversy as provincial governments quickly demanded a higher share of the revenue, given that they would be responsible for overseeing the distribution of marijuana and the administration of sundry programs. Eventually, the federal government and the provinces agreed on a $75 \%---25 \%$ split in favor of the provincial governments with a review taking place after two years. Provinces may levy their own retail sales tax on marijuana and recover distribution costs, be it through province-run stores, private distributors or some combination thereof. The auditing of taxes will, of course, be an important function that will need to be performed.

Not only does the federal government need to enact legislation, but each province will need to enact its legislation. Provincial acts can logically only be passed after the federal government passes its legalization as provincial legislatures cannot authorize illegal substances. In each province the method of distribution would need to be specified, whether it be through provincially run stores or privately held distribution sites or by a combination of a private-government arrangements. Public sector auditing conducted through the auditors-general of various provinces could be significantly different than private sector audits. Moreover, the governments are allowing the cultivation and production of marijuana to remain in private sector companies, but then in most jurisdictions to have distribution in the hands of government agencies. While this practice is not unlike the distribution of alcohol, appropriate auditing standards and procedures still need to be developed. The awarding of contracts to marijuana producers may well come under provincial guidelines surrounding the awarding of contracts and could conceivably need a transparent tendering process to ensure public sector accountability. There are barriers to entry which may well be magnified given the nature of the industry and subsequently reflected in the accounting and auditing standards and procedures.

Auditors may need to rely on other experts to attest to various parts of the value chain for both assets and liabilities. For example, in the pension industry when auditing a pension, auditors rely on actuarial reports as sufficient evidence that the liability of future anticipated distributions of the fund is appropriate and whether or not the assets held by the fund are of investment grade quality, such as bond ratings or legal lists for shares. But, how does the auditor judge the quality of the asset produced and what is a typical yield from cultivation? Are there problems of shrinkage in cultivation that an auditor would need to assess?

A major question would be, what is the appropriate tax base? The proposed taxes are flat or proportional taxes based on weight, i.e. the number of grams, but is that necessarily the optimal way to tax marijuana? The tax base might be better applied to a joint or marijuana cigarette on a per-unit basis or the amount of THC or CBD in the marijuana purchased, which is akin to the higher the alcohol content the greater the tax in the beer/wine/spirits market. The major problem with the active ingredient approach 
is that there is currently no accurate way to measure the amount of active ingredient in marijuana except by destruction testing, which is very expensive. Moreover, the presence of the active ingredient may not be consistent for the entire batch.

Market forces may more than adequately account for the determination of the quality and amount of the active ingredient as the discriminating consumer in its consumption will recognize this effect and be willing to pay more for what is perceived as a superior product, which will lead to a higher price and higher sales tax revenue.

It will also be difficult to measure and audit other forms of marijuana, such as cannabis edibles and in tincture of marijuana. All these concerns bring up the issue as to who exactly are the experts in this area and whether or not these experts would be accredited by an external agency. The provision of attestation and assurance are of prime concern and yet there is not an agency which can readily aid the auditor in this regard.

Notwithstanding that there are problems in gaining external experts for the audit, there is also the concern as to how auditors would be trained to conduct an audit. In many instances there are accounting and auditing standards that are endemic to specific industries, such as the oil and gas industry. However, what standards would need to be developed and then applied to the cannabis industry are at this point more conjecture than anything else. Obviously, accounting firms with experience in the agribusiness or the alcohol beverage sectors may have an advantage in performing these audits, but there may well be too large a degree of discretion on behalf of the auditor in signing off on financial statements. The designation of one partner as the marijuana or cannabis partner may become a necessity. Would the designation as the marijuana partner carry any type of stigma?

Financial statements requiring audits are a necessity as marijuana-based companies will trade on the exchanges. There is merger activity for various firms which require accurate earnings on which to base offering prices and perform the relevant due diligence. Moreover, these companies are entering into joint ventures across international boundaries (with the Netherlands, for example) and will need to adhere to tax laws, rules and regulations in other jurisdictions which may necessitate adherence to differing auditing standards.

As well, the grow-up can also grow additional crops, such as tomatoes, within the same facilities. Does the presence of non-regulated and regulated crops in the same facility provide for additional auditing issues? As was demonstrated earlier in this study, the only expenses allowed in marijuana grow ups were those related to the cost of goods sold. Accordingly, multiple crops in the same facility may require the development of specific formulas and standardized cost procedures to apportion costs correctly. In the longer term a hybrid between marijuana and tomatoes may provide really interesting issues. If nectarines can be developed could a tomatijuana become a reality?

Within Canada, there may need to be a dispute-resolving commission between various provincial jurisdictions and the federal government, as well between the provinces. These potential problems may only be exacerbated between nation states and international standards. Consider a potential case that a company can be incorporated and conducting business in both British Columbia and Washington State as legal entities post July 2018 in the marijuana business. Yet, they cannot export products to one another, but would have to consolidate financial statements. If they were to multi list on both a Canadian stock exchange and an American stock exchange, they would face a plethora of accounting, auditing and listing requirements, as well as dealing with both the CRA and the IRS in addition to provincial, federal, state, stock exchanges and various other agencies. Overall, there may well be many profitable opportunities for marijuana companies, but there are numerous issues that need to be hashed out. 


\section{CONCLUSION}

Overall the issues are significant, but do auditors have the time to learn and implement these procedures to ensure transparency, accountability, and compliance involved in the cultivation, distribution and sales of recreational marijuana by both government departments, private and public corporations? The auditing of recreational marijuana as has been demonstrated in this paper is still in its infancy in the United States. While Canada may have adequate auditing procedures for marijuana's medical usage, there are still several issues that must be addressed in the transition toward recreational marijuana. These issues will need to be hashed out to give necessary assurance and due diligence to shareholders in publicly traded companies and to comply with legal standards by dealing in a controlled substance.

\section{REFERENCES}

'A mad green rush': As marijuana booms, analysts still hazy on the impact of Canadian legalization on costs. (n.d.). Financial Post. http://business.financialpost.com/commodities/agriculture/amidmarijuana-boom-cost-data-leave-analysts-dazed-and-confused. Accessed on 11/14/2017.

AICPA (issued July 24, 2015, updated January 8, 2016). An Issue Brief on State Marijuana Laws and the CPA Profession. AICPA in conjunction with the Colorado Society of Certified Public Accountants and the Washington Society of Certified Public Accountants.

AICPA (n.d.), Providing Services to Businesses in the Marijuana Industry, https://www.aicpa.org/advocacy/state/pages/marijuana.aspx. Accessed on 10/13/2017

Alice of I Love Growing Marijuana (2017), Attorney General [Jeff Sessions] and Cannabis Auditing is [sic] Coming to Oregon, I Love Growing Marijuana, September 20, 2017, http://www.ilovegrowingmarijuana.com/attorney-general-cannabis-auditing-coming-oregon accessed on $10 / 13 / 2017$

Amid the 'green rush,' suits are taking over Canada's cannabis industry. (2017). Financial Post. http://business.financialpost.com/commodities/agriculture/amid-the-green-rush-suits-are-takingover-canadas-cannabis-industry. Accessed on 11/06/2017

Arrowsmith, R. (2017). IRS goes green: Hashing out payments from the marijuana industry. Accounting Today. https://www.accountingtoday.com/opinion/irs-goes-green-hashing-out-payments-fromthe-marijuana-industry. Accessed on 10/13/2017

California Cannabis CPA (2017), Lowering the Risk of an IRS Audit for your Marijuana Business, http://www.californiacannabiscpa.com/blog/lowering-the-risk-of-an-irs-audit-for-your-marijuanabusiness. Accessed on 10/13/2017.

Camico. (n.d.). Marijuana Business Clients: 'Smokin' Hot' Issues for CPAs. http://www.camico.com/blog/Marijuana_Business_Clients_Smokin_Hot_Issues for_CPAs Accessed on 10/13/2017.

Canadian Press. (2017). Aurora Cannabis's battle for CanniMed turns hostile. Financial Post. http://business.financialpost.com/investing/aurora-going-ahead-with-cannimed-offer-after-failingto-reach-deal-with-board. Accessed on 11/20/17.

Canadian Press. (2017). Canopy Growth reports \$1.3-million loss despite doubling its revenue. The Toronto Star. https://www.thestar.com/business/2017/11/14/canopy-growth-reports-13-millionloss-despite-doubling-its-revenue.html. Accessed of 11/23/17

Cannacomply (n.d.), Accounting for the Cannabis Industry, http://cannacomply.net/accounting-services. accessed on 10/13/2017

CNW Group (2016), Canna Score Compliance Auditing for Cannabis-Related Businesses, Used by Banks and Financial Institutions, CNW Group, http://www.cscomply.com. accessed on 10/13/2017

Colorado-Department of Revenue (n.d.), Marijuana Tax Data, https://www.colorado.gov/pacific/revenue/colorado-marijuana-tax-data. accessed 10/05/2017

Coren, Michael J. (2016), The pot industry is desperate for good accounting software, Quartz https://qz.com/842792/the-pot-industry-is-looking-awfully-boring. accessed 10/13/2017 
Cornelius CPA (n.d.), Cannabis Accounting Services, http://corneliuscpas.com/cannabis accounting.php. accessed on 10/13/2017

Daniels, Jeff (2016), IRS said to be auditing Colorado marijuana businesses, $C N B C$, https://www.cnbc.com/2016/07/2016/irs-said-to-be-auditing-colorado-marijuana-businesses.html. accessed on $10 / 13 / 2017$

Denver Consulting Group (n.d.) Cannabis Compliance Audits, http://denverconsultinggroup.com/how-toown-a-retail-marijuana-business/cannabis-compliance-audits. accessed 10/13/2017

Descoteaux, David (2018), The pot frenzy, CPA Canada Pivot Magazine (April 2018), https://www.cpacanada.ca/en/news/analysis/2018-04-15-the-pot-frenzy, accessed July 10, 2018.

Dollow, Clay (2017), Paying taxes in cash, marijuana companies has a lot to hash out with IRS, CNBC, https://www.cnbc.com/2017/04/18/marijuana-companies-sending-a-huge-cash-roll-to-irs-on-taxday.html. accessed on 10/13/2017

Engel, Greg (2016), Planning for the future of cannabis in Canada, Policy Options, http://policyoptions.irpp.org.magazines/june-2016/planning-for-the-future-of-cannabis-in-canada. accessed on 10/05/2017

Finkenbinder, Cynthia (2016), Cannafinance Accounting: The Necessary Evil for a Successful Cannabis Business, Cannabiz Journal (June 23, 2016), http://cannabizjournal-june2016.com. accessed $10 / 05 / 2017$

Freeman, Sunny (2017), 'Biological assets': Accounting rules are adding haze to marijuana company financials, Financial Post, http://business.financialpost.com/commodities/agriculture/biologicalassets-accounting-rules-are-adding-haze-to-marijuana-company-financials. accessed on $10 / 13 / 2017$

Hajizadeh, Mohammad (2016), Legalizing and Regulating Marijuana in Canada: Review of Potential Economic, Social and Health Impacts, International Journal of Health Policy and Management, 5(8), 453-456.

Henry Levy Group (2014), 8 Common Accounting Problems Cannabis Businesses Face, The Henry Levy Group: A CPA Firm, https://www.leafly.ca/news/industry/8-common-accounting-problemscannabis-businesses-face. accessed 10/13/2017

Lexology (2017), Task Force Report: Taxation and Pricing of Cannabis, Lexology (January 6, 2017), https://www.lexology.com/library/detail.aspx?g=6151dd9d-7688-414f-85ea-c0a04baf294a. accessed 10/05/2017

Ligaya, Armina (2017), Aurora pushes ahead with CanniMed takeover after getting no reply from board, The Toronto Star, https://www.thestar.com/business/2017/11/20/aurora-pushes-ahead-withcannimed-takeover-after-getting-no-reply-from-board.html. accessed 11/23/17

Lu-Andrews, Ran \& Chongyu Wang (2017), IPO Spillover Effects in a New and Uncertain Sector: The Case of a Marijuana REIT. Working Paper, California Lutheran University.

Market Wired (2017), Marijuana Company of America Has Engaged Auditing Firm to Prepare for Move to Fully Reporting Public Company http://www.marketwired.com/press-release/marijuanacompany-america-hasengaged-auditing-firm-prepar-move-fully-reporting-public-2185472.htm. accessed on 10/13/2017

McCullough, Michael (2018), A Bucketload of Trouble, CPA Canada Pivot Magazine, https://www.cpacanada.ca/en/news/pivot-magazine/2018-05-04-pivot-pot-bucketload-of-trouble (May, 2018).Accessed July 10, 2018.

Migoya, David (2017), DOJ is secretly using IRS to investigate Colorado pot shops in guise of audits, lawsuit says: IRS says it just wants to determine what shop owes in taxes, The Denver Post, http://www.denverpost.com/2017/09/01/lawsuit-doj-irs-investigate-colorado-pot-shops. accessed $10 / 13 / 2017$

Nevada-Department of Taxation (n.d.), Marijuana Regulations, https://tax.nv.gov/FAQs/Marijuana_Proposed_Temporary_Regulation_T002-17. accessed on $10 / 05 / 2017$ 
Olive, David (2017), 6 reasons an investment in the pot industry will likely go up in smoke: Olive, The Toronto Star, https://www.thestar.com/business/2017/11/17/6-reasons-an-investment-in-the-potindustry-will-likely-go-up-in-smoke-olive.html. accessed on 11/23/17

Oregon Cannabis Institute (n.d.), Accounting \& Bookkeeping https://oregoncannabisinstitute.com/accounting-bookkeeping. accessed on 10/13/2017

PDH Academy (2017), Changes You Need to Know-The 2017 FASB Review (Items \#30 and 30E), PDH Academy, Pewaukee, WI

Philips, Richard (2015), Issues with Taxing Marijuana at the State Level, The Institute on Taxation \& Economic Policy.

Quinn, Greg \& Hertzberg, Erik (2017), StatCan to include marijuana in GDP accounts as legalization nears, The Toronto Star, https://www.thestar.com/business/economy/2017/11/21/statcan-toinclude-marijuana-in-gdp-accounts-as-legalization-nears.html. accessed on 11/23/17

Robertson, Dylan. (2017), Pallister balks at Trudeau's proposed 10 per cent tax on cannabis, Winnipeg Free Press, https://www.winnipegfreepress.com/local/pallister-balks-at-trudeaus-proposed-10per-cent-tax-on-cannabis. accessed on 10/05/2017

Schiller, Melissa (2017), New Compliance Tools Designed to Simplify Auditing: Simplifya's CTO shares how cultivators can use the software to increase compliance through self-audits and better prepare for state inspections, Cannabis Business Times, http://www.cannabisbusinesstimes.com/article/simplifya-software-cannabis-state-audits. accessed on $10 / 13 / 2017$

Schroyer, John (2017) Industry snapshot: Accounting Services for Marijuana Businesses-Data, trends and challenges, Marijuana Business Magazine, https://mjbizmagazine.com/industry-snapshotaccounting-services-for-marijuana-businesses. accessed 10/13/2017

Siebert, Amanda (2017), Trudeau wants to impose a 10-percent federal tax on recreational cannabis, Georgia Straight Vancouver's News \&Entertainment Weekly, https://www.straight.com/cannabis/976026/trudeau-wants-impose-10-percent-federal-taxrecreational-cannabis. accessed 10/05/2017

Skerritt, Jen (2017), Aurora Cannabis' offer to buy CanniMed would be Canada's biggest marijuana takeover yet, Financial Post, http://business.financialpost.com/investing/cannabis-grower-auroraproposes-industrys-largest-takeover. Accessed on 11/16/2017

Smalley, Craig (2017), Big Tax Changes Could Be Coming for the Cannabis Industry (April 12, 2017), https://www.accountingweb.com/tax/business-tax/big-tax-changes-could-be-coming-for-thecannabis-industry. accessed on 10/05/2017

Speights, Keith (2017), Surprise! The Market for Canadian Marijuana Stocks Could Be 2 Times Bigger Than Expected, The Motley Fool (November 5, 2017), https://finance.yahoo.com/news/surprisemarket-canadian-marijuana-stocks-140100643.html. accessed on 11/14/2017

Tax Audit Pros-Certified Public Accountants (CPAs) (2017), Marijuana Accountants for Cannabis Industry. http://taxauditpros.com. accessed 10/05/2017

Thomson Reuters (2017), Canadian marijuana stocks surrender highs as challenges loom before legalization, Financial Post, http://business.financialpost.com/investing/market-moves/canadaweed-stocks-come-off-high-as-challenges-loom-before-legalization. accessed 11/20/17

Trudeau, Matthew (2017), Marijuana taxes in Canada, News Lift, http://news.lift.co/marijuana-taxescanada. accessed 10/05/2017

Valiante, Guiseppe (2017), Supreme Court of Canada case on state-run alcohol monopolies would likely impact provinces' legal pot plans, The Toronto Star, https://www.thestar.com/news/canada/2017/11/22/supreme-court-case-on-state-run-alcoholmonopolies-would-likely-impact-provinces-legal-pot-plans.html. accessed on 11/23/17

Ward, Ron (2017), Amsterdam cannabis firm to set up Canadian base in joint venture with Canopy Growth, The Toronto Star, https://www.thestar.com/business/2017/11/17/amsterdam-cannabisfirm-to-set-up-canadian-base-in-joint-venture-with-canopy-growth.html. accessed on 11/23/17 
Webb, Stevens (2015), A Cannabis Niche for Accountants? Working with Businesses that Grow and Sell Marijuana, CPA Practice Advisor, http://www.cpapracticeadvisor.com/accounting-audit. accessed on $10 / 13 / 2017$

Wells, Jane (2014), Accountants exhale after IRS takes stand on pot, CNBC https://www.cnbc.com/2014/11/20/accountants-exhale-after-irs-takes-stand-on-pot.html. accessed on $10 / 13 / 2017$

Wolter, Robert Jeffrey (2017), Sales and Use Taxes on Weed, Nesteggg [sic] Accounting, http://www.nesteggg.com/news/sales-and-use-taxes-on-weed. accessed on 10/13/2017

Yakowicz, Will (2016) Why the IRS is 'Aggressively Auditing a Bunch of Colorado Cannabis Company, INC.com, https://www.inc.com/will-yakowicz/irs-aggressively-auditing-marijuanacompanies.html. accessed on 10/13/2017 